Research Article

\title{
Detection of Selenium and Nickel Metal Ion in Water Using $\mathrm{Mn}_{3} \mathrm{O}_{4}$-Cn-Modified Electrode
}

\author{
Neetha John (iD) and K. E. Abraham (iD \\ Department of Physics, St. Berchmans College, Changanassery, Kerala 686101, India \\ Correspondence should be addressed to Neetha John; neetharj@gmail.com
}

Received 27 October 2020; Revised 14 December 2020; Accepted 20 May 2021; Published 31 May 2021

Academic Editor: Hamish Andrew Miller

Copyright (C) 2021 Neetha John and K. E. Abraham. This is an open access article distributed under the Creative Commons Attribution License, which permits unrestricted use, distribution, and reproduction in any medium, provided the original work is properly cited.

\begin{abstract}
The present study reports the design of the $\mathrm{Mn}_{3} \mathrm{O}_{4}$-Cn electrode and its use for simultaneous detection of selenium and nickel in water. The designed electrode can be used as a convenient electrochemical device for on-site testing of Se (IV) and Ni (II) levels in affected regions. The best responses are obtained with $0.1 \mathrm{M}$ phosphate buffer saline (PBS) and $5 \mathrm{mM}$ Fe $(\mathrm{CN})_{6}$ as supporting electrolyte. The scan rate and the number of cyclic repetitions have a great effect on peak shape and intensity. It is seen from our study that peak intensity is directly proportional to Se (IV) and Ni (II) concentrations in the range of 5 to $250 \mu \mathrm{g} / \mathrm{L}$ (correlation coefficients 0.952 and 0.984 ) when the optimized parameters are used. The detection limit of $0.533 \mu \mathrm{g} / \mathrm{L} \mathrm{Se}$ (IV) and $0.718 \mu \mathrm{g} / \mathrm{L}$ for $\mathrm{Ni}$ (VI) with a response time of $18 \mathrm{~s}$ for $5-250 \mu \mathrm{g} / \mathrm{L}$ concentration is obtained, respectively. Enhanced analytical results for different water samples establish that the proposed method is appropriate for Se (IV) and Ni (II) detection. FESEM images confirm the $\mathrm{Mn}_{3} \mathrm{O}_{4}$-Cn nanocomposite formation on the electrode.
\end{abstract}

\section{Introduction}

Heavy metals in the environment pose a great hazard to organisms owing to their nonbiodegradability [1]. Numerous research laboratories are using systematic procedures to analyze metal ions in various mediums. This consists of atomic absorption spectrometry, atomic fluorescence spectrometry, high-pressure liquid chromatography, gas chromatography, and flow injection analysis [2]. But, these techniques have their own drawbacks. Electrochemical detection of metal ions has several advantages such as low cost, on-site availability, stability, repeatability, accuracy, and detection of multiple ions. Cyclic voltammetry (CV) is a method to recognize and differentiate redox behavior, stability, and surface area of the working electrode used for electrochemical sensing $[3,4]$.

This technique using modified electrodes is to provide selectivity toward few metal ions. However, the selection of working electrodes is vital for the achievement of $\mathrm{CV}$ analysis. There are many reports based on different metal oxide nanoparticles [5-13]. Manganese oxide nanoparticles are among the most suitable contenders as electrode material owing to their catalyst nature, low cost, stability, nontoxic nature, large surface area, low detection limit, natural abundance, and high energy density [14-20]. John reported the excellent gas sensing properties of $\mathrm{Mn}_{3} \mathrm{O}_{4}$ nanorods [20]. Nowadays, due to the progress of nanoscience and nanotechnology, there are numerous ways of fabricating chemically modified electrodes using nanocomposites. A clever candidate to form nanocomposite with $\mathrm{Mn}_{3} \mathrm{O}_{4}$ is Chitosan. Chitosan $(\mathrm{Cn})$ is a polysaccharide polymer with attractive properties like thin film-forming capability, good adhesion, and outstanding sensitivity [13]. Chitosan consists of volatile amino and hydroxyl functional groups which enable strong enzyme affinity and chemical modifications [18]. There are only a few works reported for metal ion detection based on these materials $[2-4,13] . \mathrm{Mn}_{3} \mathrm{O}_{4}$ is known for its high electrocatalytic nature which makes it an excellent electrode for gas sensors and biosensors. However, a mixture of $\mathrm{Cn}$ and $\mathrm{Mn}_{3} \mathrm{O}_{4}$ is yet to be tried for trace metal ion detection. In the present work, an electrochemical sensor is developed for selenium and nickel detection in various water sources by 
modifying a platinum $(\mathrm{Pt})$ electrode with manganese oxide $\left(\mathrm{Mn}_{3} \mathrm{O}_{4}\right)$ and chitosan. Selenium and nickel are toxic to the environment if their levels are above the required limit. Freshwaters are being contaminated by the dumping of toxic metal ions as a result of industrialization. So, it is very vital to determine these metal ion traces in freshwaters before usage. To the best of our knowledge, this is the first report of electrochemical selenium and nickel sensor based on $\mathrm{Mn}_{3} \mathrm{O}_{4}$-Cn nanocomposite, that too for selenium and nickel level detection in lake water.

\section{Experimental}

2.1. Materials and Synthesis. All the chemicals are of analytical grade and used without further purification. Stock solutions of $\mathrm{Se}(\mathrm{IV}), \mathrm{Ni}$ (II) of $1000 \mu \mathrm{g} / \mathrm{L}$, and ions like $\mathrm{Cd}^{2+}$, $\mathrm{Mg}^{2+}, \mathrm{Fe}^{2+}, \mathrm{As}^{2+}, \mathrm{PO}_{4}{ }^{3-}, \mathrm{I}^{-}, \mathrm{Cu}^{2+}, \mathrm{Br}^{-}, \mathrm{Pb}^{2+}, \mathrm{Li}^{2+}, \mathrm{Ba}^{2+}$, $\mathrm{SO}_{4}{ }^{2-}$, and $\mathrm{Fe}(\mathrm{CN})_{6}$ are brought from Merck and stored in refrigeration. Water for selenium and nickel detection is collected from a lake in South India, which is known for its toxicity due to the immense dumping of the waste from industrial and fertilizer factories. In commercial fertilizers, selenium is added in trace amounts. But, an ample amount is added up in the waste which polluted the surrounding water resources. Selenium and nickel act as a pollutant due to factory waste dumped into the water resources and lakes especially. Samples are collected from different sites of lakes and rivers during monsoon and summer. Anodic aluminum oxide $(\mathrm{AAO})$ template with a length of $60 \mu \mathrm{m}$ and having a pore diameter of $350 \mathrm{~nm}$ (Smart membranes, Germany) are purchased for the synthesis. We took $1 \mathrm{M}$ manganese acetate $(5.13 \mathrm{~g})$ is dissolved in $100 \mathrm{ml}$ of deionized (DI) water and stirred it for 20 minutes [20]. While stirring, we added $1 \mathrm{M}$ ammonium hydroxide $(100 \mathrm{ml})$ slowly. This solution is magnetically stirred for around one hour, resulting in a brown solution. Later, it is subjected to hydrothermal reaction, setting the temperature to $170^{\circ} \mathrm{C}$ for $7 \mathrm{hr}$. The resultant mixture is then washed with distilled water and dried at $60^{\circ} \mathrm{C}$ for $9 \mathrm{hr}$. The dried powder is annealed at $300^{\circ} \mathrm{C}$ for $2 \mathrm{hr}$, which produced pearl-shaped nanostructures, which are sonicated for $60 \mathrm{~s}$ in ethanol. This mixture is then filled into the pores of the AAO template by vacuum infiltration technique [20]. The AAO template is then air-dried at room temperature. This process leads to the development of aligned nanorods. These nanorods from AAO are separated to fabricate the biosensor, $\mathrm{Mn}_{3} \mathrm{O}_{4}$ nanorods are sonicated in ethanol for one hour, and the residue is washed again in ethanol. The residue obtained is then dried at $60^{\circ} \mathrm{C}$ for 5 hours, which resulted in an ensemble of $\mathrm{Mn}_{3} \mathrm{O}_{4}$ nanorods without any support.

2.2. Fabrication of $\mathrm{Pt} / \mathrm{Mn}_{3} \mathrm{O}_{4} / \mathrm{Cn}$ Working Electrode. The working electrode is prepared where $20 \mathrm{mg}$ of $\mathrm{Mn}_{3} \mathrm{O}_{4}$ nanorods separated from AAO is added to $5 \mathrm{ml}$ of chitosan solution prepared when $1 \mathrm{gm}$ chitosan is dispersed in $100 \mathrm{ml}$ of $0.1 \mathrm{~m}$ acetic acid [13]. When the solution is stirred, $\mathrm{Mn}_{3} \mathrm{O}_{4}$ - $\mathrm{Cn}$ suspension is formed. The $\mathrm{Mn}_{3} \mathrm{O}_{4}$ - $\mathrm{Cn}$ electrode is formed when $2 \mu \mathrm{L}$ of this aliquot is uniformly coated on the Pt working electrode by drop cast method. Performance of $\mathrm{Pt} / \mathrm{Mn}_{3} \mathrm{O}_{4}$ - $\mathrm{Cn}$ electrode for selenium and nickel detection in lake water is investigated as a real-time application. At first, the electrode is exposed to different trials to gain recovery when spiking different concentrations of selenium and nickel in supporting electrolytes $[10,11]$.

2.3. Characterization. Morphology of $\mathrm{Mn}_{3} \mathrm{O}_{4}$ nanorods separated from AAO and $\mathrm{Mn}_{3} \mathrm{O}_{4}-\mathrm{Cn}$ is characterized by Field Emission Spectroscopic Electron Microscopy (FESEMJOEL). FESEM is also used to confirm nanocomposite formation. The Fourier Transform Infrared (FT-IR, Spectrum 400, Perkin Elmer) spectra of $\mathrm{Mn}_{3} \mathrm{O}_{4}-\mathrm{Cn}$ and $\mathrm{Mn}_{3} \mathrm{O}_{4^{-}}$ $\mathrm{Cn} / \mathrm{Se}$ and $\mathrm{Ni}$ are used to justify the absorbed peaks related to each component of the material. $\mathrm{CV}$ is a three-electrode arrangement that consisted of a working electrode, a reference electrode, and a counter electrode. All voltammetry experiments are conducted at room temperature in a $\mathrm{CV}$ system (Biologic SP-200, Germany) which involved a Pt/ $\mathrm{Mn}_{3} \mathrm{O}_{4}$-chitosan electrode (working electrode), platinum wire as a counter electrode, and $\mathrm{Ag} / \mathrm{AgCl}$ as reference electrodes.

\section{Results and Discussion}

3.1. Field Emission Spectroscopy and Fourier Transform Analyses. The morphology of $\mathrm{Mn}_{3} \mathrm{O}_{4}$ nanorods separated from AAO is characterized using FESEM which is illustrated in Figure 1(a). The surface morphology of $\mathrm{Mn}_{3} \mathrm{O}_{4}-\mathrm{Cn}$ is observed using FESEM confirming nanocomposite formation as shown in Figure 1(b). It is seen that chitosan has closely anchored on $\mathrm{Mn}_{3} \mathrm{O}_{4}$ nanorods forming $\mathrm{Mn}_{3} \mathrm{O}_{4}$-Cn nanocomposite. The nanorods exhibit a well-aligned and active surface area for selenium mobilization. From FESEM, the average diameters of $\mathrm{Mn}_{3} \mathrm{O}_{4}$ and $\mathrm{Mn}_{3} \mathrm{O}_{4}$ - $\mathrm{Cn}$ are $300 \pm 2.3 \mathrm{~nm}$ and $335 \pm 4.7 \mathrm{~nm}$, respectively. The electrodes are thoroughly washed and rinsed with Millipore water.

3.2. Electron Impedance Spectroscopy. Electrochemical impedance spectroscopy (EIS) is an efficient method to understand interfacial electron transfer due to changes at the electrode surface while being modified [10]. Fe $(\mathrm{CN})_{6}$ is used as the redox probe in impedance measurements conducted in PBS media at $\mathrm{Mn}_{3} \mathrm{O}_{4}$ and $\mathrm{Mn}_{3} \mathrm{O}_{4}$-Cn electrodes. EIS measurements are carried out using $1 \mathrm{~Hz}$ to $100 \mathrm{kHz}$ with an alternating voltage of $5 \mathrm{mV}$ and a bias potential of $0.5 \mathrm{~V}$ (Figure 2). The semicircle at higher frequencies denotes the electron transfer resistance $\left(\mathrm{R}_{\mathrm{ct}}\right)$, and the linear part at lower frequencies connotes the diffusion process. A definite semicircle is exhibited by $\mathrm{Mn}_{3} \mathrm{O}_{4}$ at a higher frequency. It is noted that the semicircle is reduced, which implies the charge relocation resistance once $\mathrm{Mn}_{3} \mathrm{O}_{4}$ is modified with $\mathrm{Cn}$. This shows that $\mathrm{Mn}_{3} \mathrm{O}_{4}-\mathrm{Cn}$ is an excellent conducting material and it can accelerate electron transfer.

3.3. Electrochemical Characterization. When a potential is applied to the working electrode, it sweeps back and forth for 


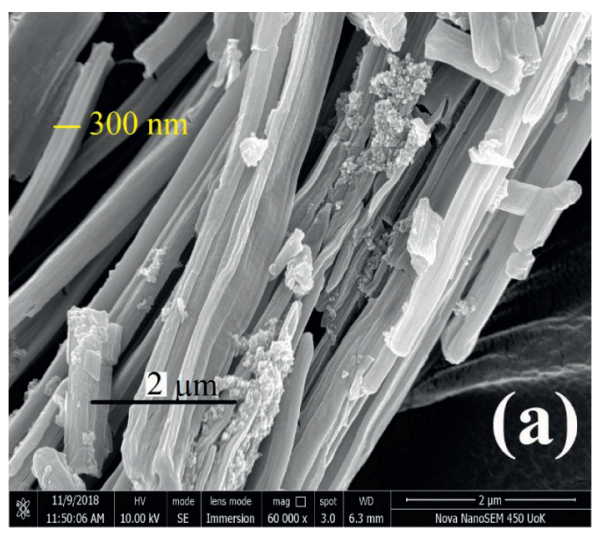

(a)

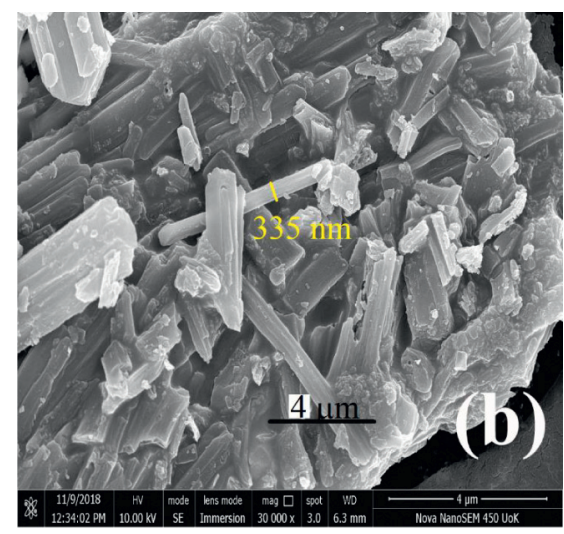

(b)

Figure 1: FESEM image of (a) $\mathrm{Mn}_{3} \mathrm{O}_{4}$ and (b) $\mathrm{Mn}_{3} \mathrm{O}_{4}$-Cn.

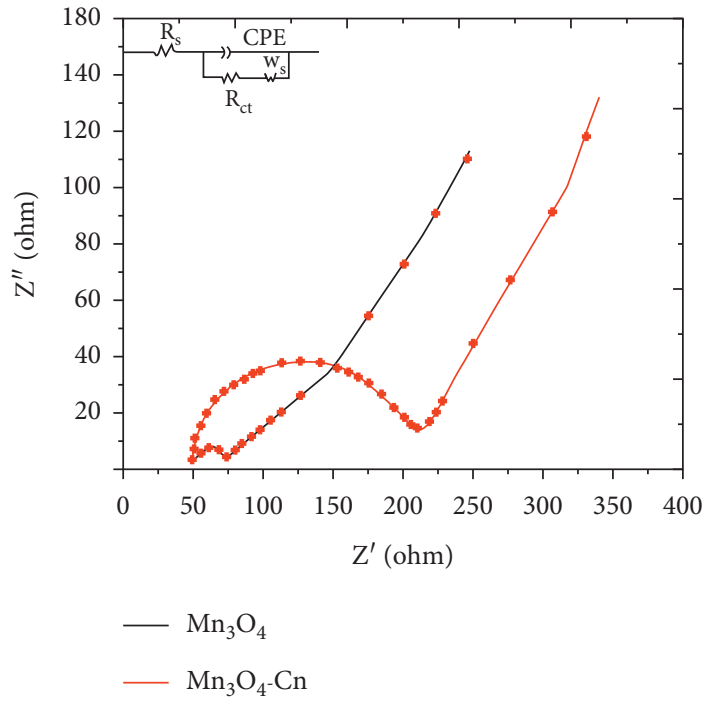

Figure 2: EIS of $\mathrm{Mn}_{3} \mathrm{O}_{4}$ and $\mathrm{Mn}_{3} \mathrm{O}_{4}$ - $\mathrm{Cn}$ in $0.1 \mathrm{M}$ PBS and $5 \mathrm{mM} \mathrm{Fe}$ $(\mathrm{CN})_{6}$.

a definite number of cycles according to the given range of voltage and speed of voltage sweep, and subsequent current at the working potential is measured [5]. This current is then plotted against the potential to draw a CV graph that provides a deep perception about the material regarding the anodic peak current $\left(I_{p a}\right)$ from the oxidation process and about cathodic peak current $\left(I_{p c}\right)$ from the reduction process that occurred on working potential. Potentials, where peak currents happen, are called peak potentials (Ep). We can examine the reversibility of reactions happening at the electrode surface by increasing the scan rates [6].

Electrochemical reversible reactions arise from fast electron transfer between ions and electrodes, which will be slower in irreversible reaction [6-10]. The applicability of modified $\mathrm{Mn}_{3} \mathrm{O}_{4}$-Cn as a potential electrochemical sensing platform for a metal solution such as Se (IV) and Ni (II) is investigated using cyclic voltammetry at a deposition potential of $400 \mathrm{mV}$. All the experiments are conducted at room temperature. The electrochemical analyses are carried out in $10 \mathrm{~mL}$ electrochemical cell with a known amount of Se (IV) and Ni (II) in $0.1 \mathrm{M}$ phosphate buffer solution ( $\mathrm{pH}$ 2) and $5 \mathrm{mM} \mathrm{Fe}(\mathrm{CN})_{6}$ as supporting electrolyte, respectively.

In $\mathrm{CV}$, the electrolyte has a vital role in the dispersal of analyte types onto the electrode [18-20]. Phosphate buffer solution (PBS) gives rise to a sharp and intense oxidation signal and is used as a supporting electrolyte in order to avoid all interferences of $\mathrm{H}^{+}$and complex compound formation that happens while using $\mathrm{HCl}, \mathrm{HNO}_{3}$, and $\mathrm{H}_{2} \mathrm{SO}_{4}$ [21]. PBS $(0.1 \mathrm{M})$ with $5 \mathrm{mM} \mathrm{Fe}(\mathrm{CN})_{6}$ acting as a redox couple is used as the supporting electrolyte and provides a good response to selenium and nickel detection [21]. PBS is examined for $\mathrm{pH}$ from 1-6 in order to detect $\mathrm{Se}$ (IV) and $\mathrm{Ni}$ (II) using $\mathrm{Mn}_{3} \mathrm{O}_{4}$-Cn sensor [21]. We observe the optimized condition for metal ion detection takes place at $\mathrm{pH}=2$ for $100 \mu \mathrm{g} / \mathrm{L}$ Se (IV) and Ni (II). Voltammetric response of Pt/ $\mathrm{Mn}_{3} \mathrm{O}_{4}$ and $\mathrm{Pt} / \mathrm{Mn}_{3} \mathrm{O}_{4}$-chitosan electrodes in PBS $(0.1 \mathrm{M})$ and $5 \mathrm{mM} \mathrm{Fe}(\mathrm{CN})_{6}$ is carried out at a scan rate of $100 \mathrm{mVs}^{-1}$ (Figure 3). We tested for different scan rates too, but without any vast variation obtained for $100 \mathrm{mVs}^{-1}$.

We noticed that the bare Pt electrode in PBS and Fe $(\mathrm{CN})_{6}$ is not showing any peak current. As we used the Pt/ $\mathrm{Mn}_{3} \mathrm{O}_{4}$ and $\mathrm{Pt} / \mathrm{Mn}_{3} \mathrm{O}_{4}$-Cn electrodes, there is a current response. Peak current with $\mathrm{Pt} / \mathrm{Mn}_{3} \mathrm{O}_{4}$-Cn electrode is more intense than that with other electrodes. This confirms that peak intensity is due to $\mathrm{Pt} / \mathrm{Mn}_{3} \mathrm{O}_{4}$-Cn electrode only. Based on the profile of the voltammogram, peak current and peak potential of Se (IV) and Ni (II) in $0.1 \mathrm{M} \mathrm{PBS}$ and $5 \mathrm{mM} \mathrm{Fe}$ $(\mathrm{CN})_{6}$ are obtained. Cyclic voltammograms of $\mathrm{Mn}_{3} \mathrm{O}_{4}$ and modified $\mathrm{Mn}_{3} \mathrm{O}_{4}$ are recorded with $0.1 \mathrm{M}$ PBS with $5 \mathrm{mM} \mathrm{Fe}$ $(\mathrm{CN})_{6}$ supporting electrolyte, at different scan rates (10 to $100 \mathrm{mV} / \mathrm{s}$ ). Figure 4 illustrates anodic peak current plot against the square root of scan rate for $\mathrm{Pt} / \mathrm{Mn}_{3} \mathrm{O}_{4}$ with $R^{2}=0.9768$ and $\mathrm{Pt} / \mathrm{Mn}_{3} \mathrm{O}_{4}$-Cn with $R^{2}=0.9978$, respectively. Their respective equation curves obtained are

$$
\begin{aligned}
& I_{p}(\mu \mathrm{A})=27.851 v^{1 / 2}+5.6938, \\
& I_{p}(\mu \mathrm{A})=36.877 v^{1 / 2}+1.5676,
\end{aligned}
$$

where $R$ is the correlation coefficient and $\mathrm{U}$ is the scan rate $[21,22]$. Evidently, peak currents of $\mathrm{Mn}_{3} \mathrm{O}_{4}$-Cn electrode are 


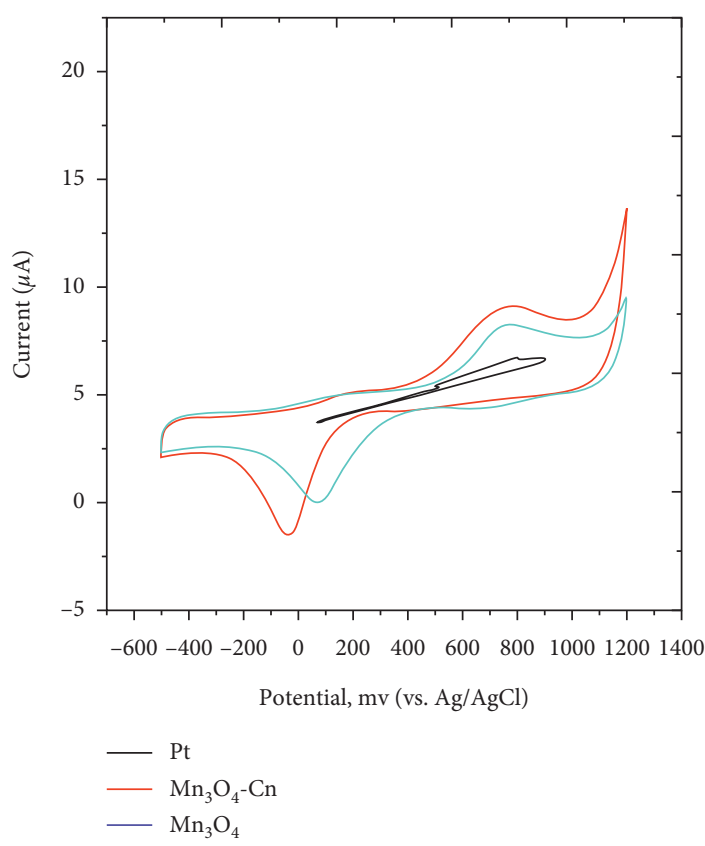

(a)

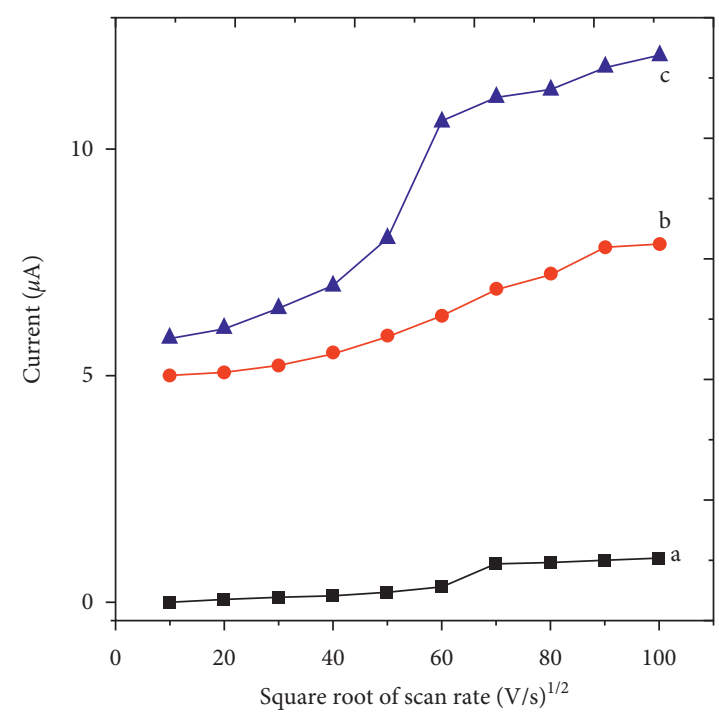

(b)

Figure 3: (a) Cyclic voltammetry plot of $\mathrm{Pt} / \mathrm{Mn}_{3} \mathrm{O}_{4}$ and $\mathrm{Pt} / \mathrm{Mn}_{3} \mathrm{O}_{4}-\mathrm{Cn}$ electrodes in $0.1 \mathrm{M} \mathrm{PBS}$ and $5 \mathrm{mM} \mathrm{Fe}(\mathrm{CN})_{6}$ with scan rate $=100 \mathrm{mV} /$ s. (b) Randle-Sevcik's plot of anodic peak current versus square root of scan rate 5 to $100 \mathrm{mV} / \mathrm{s}$ for (a) bare $\mathrm{Pt},(\mathrm{b}) \mathrm{Pt} / \mathrm{Mn}_{3} \mathrm{O}_{4}$, and (c) $\mathrm{Pt} /$ $\mathrm{Mn}_{3} \mathrm{O}_{4}-\mathrm{Cn}$ in $0.1 \mathrm{M}$ PBS and $5 \mathrm{mM} \mathrm{Fe}(\mathrm{CN})_{6}$ at $25^{\circ} \mathrm{C}$ in the range of -500 to $1200 \mathrm{mV}$.

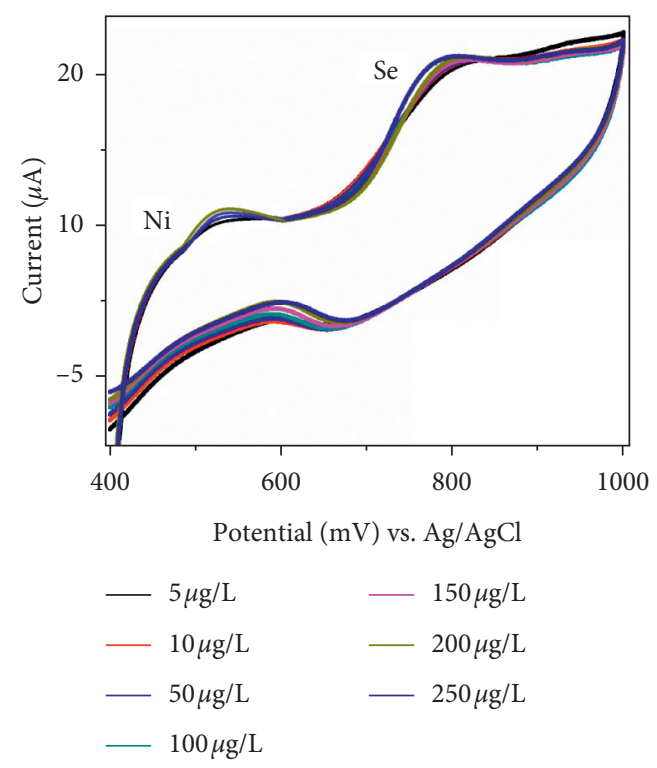

FIGURE 4: Comparative voltammograms of a solution containing Se (IV) and $\mathrm{Ni}$ (II) for different concentrations in $0.1 \mathrm{M} \mathrm{PBS}$ and $5 \mathrm{mM}$ $\mathrm{Fe}(\mathrm{CN})_{6}$ at a scan rate of $100 \mathrm{mV} / \mathrm{s}$ by $\mathrm{Mn}_{3} \mathrm{O}_{4}$-Cn electrode at $25^{\circ} \mathrm{C}$ in the range of 400 to $1000 \mathrm{mV}$.

higher than $\mathrm{Mn}_{3} \mathrm{O}_{4}$, due to more active surface area and, hence, increased conductivity after adding $\mathrm{Cn}$ [21]. The linear dependence between scan rate and oxidation current indicates that selenium and nickel are adsorbed on the surface of the $\mathrm{Pt} / \mathrm{Mn}_{3} \mathrm{O}_{4}-\mathrm{Cn}$ electrode which is due to a surface-confined electron transfer. Moreover, the current passing through the electrode is restricted by the diffusion of selenium and nickel to the electrode surface. This diffusion change is caused by the concentration gradient near the electrode $[19,20,22,23]$. This gradient is affected by the concentration of selenium and nickel at the electrode and the rate at which it can diffuse through the solution $[8,21]$. So, the diffusion coefficient can be obtained using Randles-Sevcik formula:

$$
I_{p a}=268,600 n^{3 / 2} A D^{1 / 2} C v^{1 / 2}
$$

Therefore, the obtained diffusion coefficient is $8.2 \times 10^{-6} \mathrm{~cm}^{2} \mathrm{~s}^{-1}$, where $I_{p a}$ is anodic peak current, $A$ is the active electrode surface area, $n$ is the number of mobile electrons in PBS, $U$ is the scan rate, and $C$ is the concentration of PBS [21]. Electroactive surface area is $0.055 \mathrm{~cm}^{2}$ and $0.043 \mathrm{~cm}^{2}$ for $\mathrm{Mn}_{3} \mathrm{O}_{4}-\mathrm{Cn}$ and $\mathrm{Mn}_{3} \mathrm{O}_{4}$, respectively. Afterward, cyclic voltammograms of metal ion solution of $\mathrm{Se}$ (IV) and Ni (II) concentrations between $5 \mu \mathrm{g} / \mathrm{L}$ and $250 \mu \mathrm{g} / \mathrm{L}$ are observed using the optimized conditions (Figure 4 ). The enhanced current response is due to the large specific surface area of the $\mathrm{Mn}_{3} \mathrm{O}_{4}-\mathrm{Cn}$. The improved electrochemical response of $\mathrm{Mn}_{3} \mathrm{O}_{4}$ - $\mathrm{Cn}$ arose due to the enhanced electroactive surface area and higher catalyst activity of $\mathrm{Mn}_{3} \mathrm{O}_{4}[4,16]$. This enhancement of electrochemical current response due to the uniform and well-aligned grid of $\mathrm{Pt} / \mathrm{Mn}_{3} \mathrm{O}_{4}-\mathrm{Cn}$ electrode delivers a good pathway for the passage of electrons created during oxidation of selenium and nickel which are transported to the electrode surface through $\mathrm{Mn}$ ion $[4,16]$. Also, the existence of nanorod-shaped morphology of $\mathrm{Mn}_{3} \mathrm{O}_{4}-\mathrm{Cn}$ electrode gives forth better electronic and ionic transport because of uniformly distributed $\mathrm{Mn}_{3} \mathrm{O}_{4}-\mathrm{Cn}$ rather than bulk matrix $[4,16]$. Usually, the redox kinds get 
absorbed on the electrode surface, but due to the electrochemical property of $\mathrm{Mn}_{3} \mathrm{O}_{4}$, it would decrease the absorption of redox species which will enable the electron to be electrochemically reversible. This suggests that this sensor can increase the electron transfer rate at the electrodes which enhance its performance. More conductive pathways are created for electron transfer on the surface of $\mathrm{Mn}_{3} \mathrm{O}_{4}-\mathrm{Cn}$ in PBS $[4,16,21]$. The peak current of Se (IV) and Ni (II) increased from $400 \mathrm{mV}$ to $1000 \mathrm{mV}$ because of strong absorption by the $\mathrm{Mn}_{3} \mathrm{O}_{4}$ - $\mathrm{Cn}$ sensor. Se (IV) and Ni (II) are adsorbed due to electrostatic interaction between the electrode and metal ions resulting in a high peak signal due to the intermetallic bond between $\mathrm{Mn}$ and ions [16, 19, 20, 23]. The high peak signal can also arise due to higher electron transfer capability, increase in electroactive surfaces, and conductivity resulting in higher sensitivity toward Se (IV) and $\mathrm{Ni}$ (II) ions. The potential is set at $400 \mathrm{mV}$ and reversed at $1000 \mathrm{mV}$ with a scan rate of $100 \mathrm{mV} / \mathrm{s}$. During the analysis, oxidation peak and reduction peak are detected at $730 \mathrm{mV}$ and $850 \mathrm{mV}$ for Se (IV) with $500 \mathrm{mV}$ and $600 \mathrm{mV}$ for Ni (II), respectively (Figure 4) [11-20, 23].

Those peaks are apparently associated with the redox reaction of Se (IV) and $\mathrm{Ni}$ (II) at the surface of $\mathrm{Mn}_{3} \mathrm{O}_{4}$ - $\mathrm{Cn}$. As the reduction of metal ions can occur by different mechanisms, the overall process that occurs on the surface of the electrode is considered to include reduction of Se (IV) to Se (0) and Ni (II) to Ni (0). This fact is confirmed by the alteration of the peak intensity during variation of $\mathrm{Se}$ (IV) and $\mathrm{Ni}$ (II) concentrations [11]. The analytes concentration played a vital role in the shifting of both cathodic and anodic peaks toward lower potential, but the potential difference of reduction and oxidation peaks is relatively consistent as shown in Figure 4. Based on the profile of the voltammogram, the peak current and the peak potential of Se (IV) and $\mathrm{Ni}$ (II) in $0.1 \mathrm{M}$ PBS and $5 \mathrm{mM} \mathrm{Fe}(\mathrm{CN})_{6}$ are determined.

3.4. Variation of the Scan Rate. The effects of scan rate from $25 \mathrm{mV} / \mathrm{s}$ to $200 \mathrm{mV} / \mathrm{s}$ on the electrochemical response of $\mathrm{Mn}_{3} \mathrm{O}_{4} /$ chitosan electrode in PBS $(0.1 \mathrm{M})$ and $5 \mathrm{mM} \mathrm{Fe}$ $(\mathrm{CN})_{6}$ toward $250 \mu \mathrm{g} / \mathrm{L} \mathrm{Se}(\mathrm{IV})$ and Ni (II) are investigated. From Figure 5, one can observe that some anodic peaks appeared at potential around $900 \mathrm{mV}$ to $1000 \mathrm{mV}$, while the cathodic peak is observed at a potential of around $350 \mathrm{mV}$ to $400 \mathrm{mV}$. Anodic peak $(1000 \mathrm{mV}$ and $1100 \mathrm{mV})$ and cathodic peak $(360 \mathrm{mV}$ and $370 \mathrm{mV})$ are observed for Se (IV), respectively, while, for $\mathrm{Ni}$ (II), the anodic peak is from $410 \mathrm{mV}$ to $650 \mathrm{mV}$ with a cathodic peak between $800 \mathrm{mV}$ and $1000 \mathrm{mV}$.

Majorly, electron transfer on the surface of $\mathrm{Mn}_{3} \mathrm{O}_{4}-\mathrm{Cn}$ is controlled by diffusion. We conclude that the working curves of Se (IV) and Ni (II) investigations are least limited by concentration. We observed that the reduction of Se (0) and $\mathrm{Ni}(0)$ is obtained toward the lower potential. The experiment is accomplished using Se (IV) and Ni (II) of $20 \mu \mathrm{g} /$ $\mathrm{L}$ in $0.1 \mathrm{M} \mathrm{PBS}$ and $5 \mathrm{mM} \mathrm{Fe}(\mathrm{CN})_{6}$ to 7 times of repetition at a scan rate of $25 \mathrm{mV} / \mathrm{s}$, which resulted in only a slight variation in current.

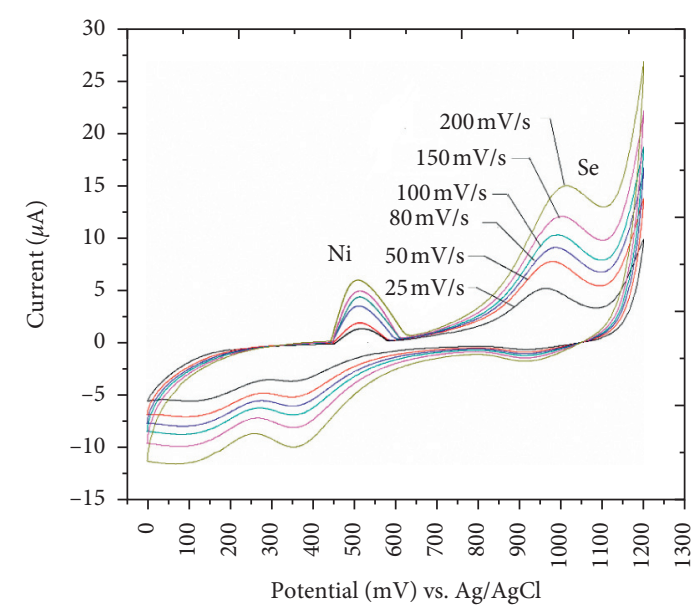

Figure 5: Cyclic voltammogram of Se (IV) and Ni (II) at a concentration of $250 \mu \mathrm{g} / \mathrm{L}$ with a variation of scan rate in $0.1 \mathrm{M}$ PBS and $5 \mathrm{mM} \mathrm{Fe}(\mathrm{CN})_{6}$ using $\mathrm{Mn}_{3} \mathrm{O}_{4}$-Cn electrode at $25^{\circ} \mathrm{C}$ in the range of -10 to $1200 \mathrm{mV}$.

3.5. Calibration Curves and Detection Limit. The fabricated $\mathrm{Mn}_{3} \mathrm{O}_{4}$-Cn electrodes exhibit excellent reusability, repeatability, and stability. The electrodes are recyclable up to 35 successive runs with relative standard deviation $<3 \%$, while a substantial reduction is observed after it, which may be due to consecutive deposition of $\mathrm{Se}(0)$ and $\mathrm{Ni}(0)$ during reduction [22, 23]. Reproducibility of $\mathrm{Mn}_{3} \mathrm{O}_{4}$-Cn electrode is confirmed using five different sets, which shows outstanding reproducibility with a standard deviation of $\sim 0.8 \%$. To estimate the stability of this electrode, $\mathrm{CV}$ response is recorded for 14 days. We noticed that the current response is diminished by $\sim 4.2 \%$, which still could be enhanced by storage situations. Thus, the $\mathrm{Mn}_{3} \mathrm{O}_{4}$ - $\mathrm{Cn}$ electrode provides improved stability, reusability, and reproducibility characteristics toward selenium (IV) and Ni (II). It is observed that a linear calibration equation exists from 5 to $250 \mu \mathrm{g} / \mathrm{L}$. Linear regression model for Se (IV) and Ni (II) for 5 to $250 \mu \mathrm{g} / \mathrm{L}$ is fitted using the following expression:

$$
\begin{array}{ll}
y=\left\{2.148 e^{-7} x-4.78 e^{-7}\right\}, & \text { for } 5 \frac{\mu \mathrm{g}}{\mathrm{L}} \text { to } 250 \frac{\mu \mathrm{g}}{\mathrm{L}}, \mathrm{Se}(\mathrm{IV}), \\
y=\left\{3.572 e^{-7} x-6.994 e^{-7}\right\}, & \text { for } 5 \frac{\mu \mathrm{g}}{\mathrm{L}} \text { to } 250 \frac{\mu \mathrm{g}}{\mathrm{L}}, \mathrm{Ni} \text { (II). }
\end{array}
$$

The calibration curve is plotted using peak current versus the concentration of Se (IV) and Ni (II) under the recommended conditions from Figures 6 and 7.

There is a linear relationship held over the concentration ranges of $5-250 \mu \mathrm{g} / \mathrm{L}$ (correlation coefficient $R^{2}=0.952$ ) for Se (IV) and Ni (II) $\left(R^{2}=0.984\right)$ as depicted in Figure 7.

The limit of detection (LOD) is calculated as

$$
C_{L}=\frac{3 S_{D}}{\mathrm{~m}},
$$

where $C_{L}, S_{D}$, and $m$ are the limit of detection, the standard deviation of the blank, and slope of the calibration graph, respectively [22]. LOD obtained is $0.533 \mu \mathrm{gL}^{-1} \mathrm{Se}$ (IV), and 


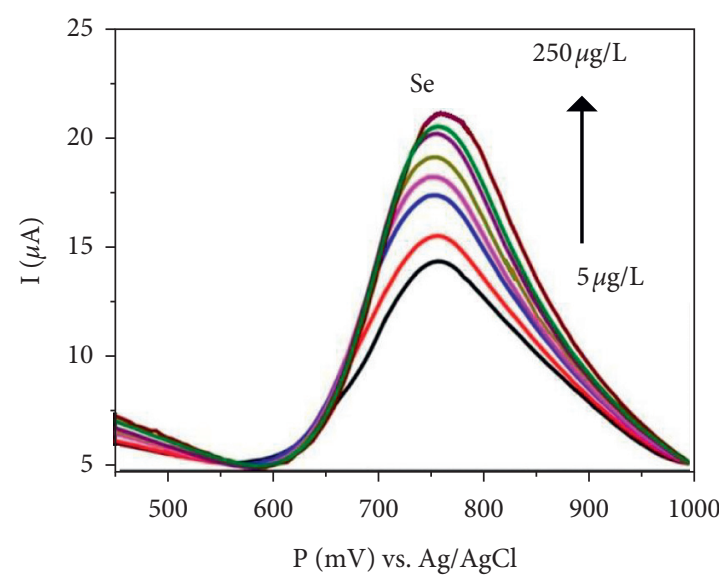

(a)

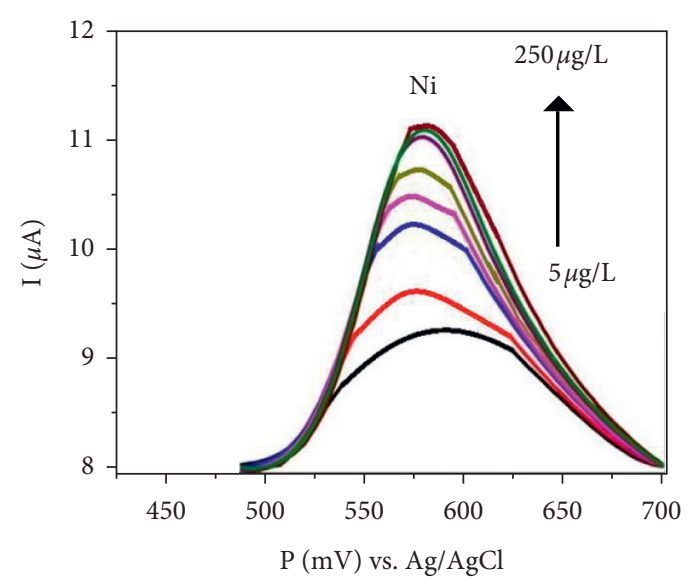

(b)

Figure 6: Magnified cyclic voltammetric curves of Se (IV) and Ni (II) for 5-250 $\mu \mathrm{g} / \mathrm{L}$ in $0.1 \mathrm{M}$ PBS and $5 \mathrm{mM} \mathrm{Fe}(\mathrm{CN})_{6}$ at a scan rate of $100 \mathrm{mV} / \mathrm{s}$ by $\mathrm{Mn}_{3} \mathrm{O}_{4}$-Cn electrode at $25^{\circ} \mathrm{C}$ in the range of 400 to $1000 \mathrm{mV}$.

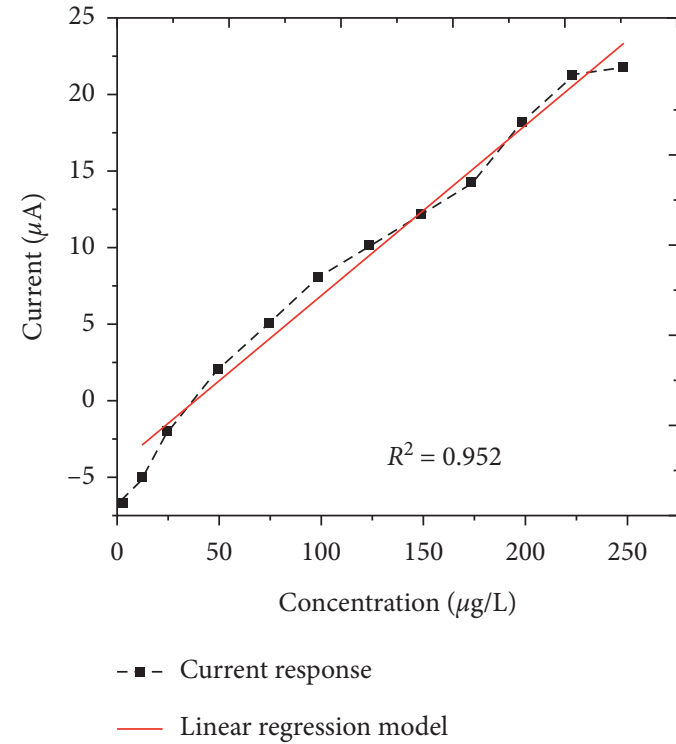

(a)

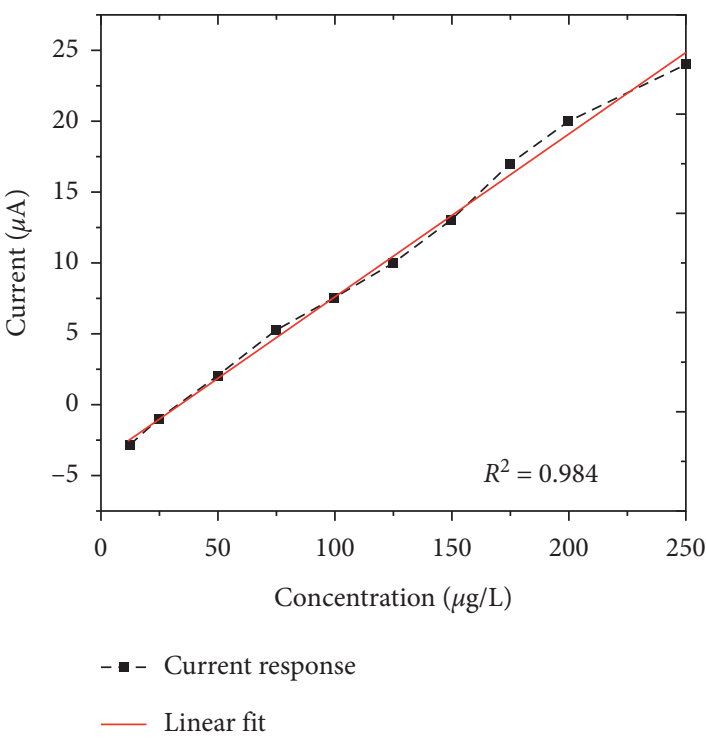

(b)

Figure 7: Calibration curve for (a) Se (IV) and (b) Ni (II) in the concentration range of 5-250 $\mu \mathrm{g} / \mathrm{L}$ in $0.1 \mathrm{M}$ PBS and $5 \mathrm{mM} \mathrm{Fe}(\mathrm{CN})_{6}$ using $\mathrm{Mn}_{3} \mathrm{O}_{4}$-Cn electrode at $25^{\circ} \mathrm{C}$.

for $\mathrm{Ni}$ (II), it is $0.718 \mu \mathrm{gL}^{-1}$, respectively, with a detection time of $18 \mathrm{~s}$. The fabricated sensor displays a satisfactory detection limit and a varied detection range essential for practical utility. Table 1 reveals the superior characteristics of $\mathrm{Mn}_{3} \mathrm{O}_{4}$ - $\mathrm{Cn}$ electrode for detection of selenium and nickel comparable to reported values.

3.6. Interference. Detection of $\mathrm{Se}$ (IV) and $\mathrm{Ni}$ (II) in the presence of additional commonly found ions in water is of high importance and significance [5-21, 23, 24]. Therefore, interference of various ions like $\mathrm{Cd}^{2+}, \mathrm{Mg}^{2+}, \mathrm{Fe}^{2+}, \mathrm{As}^{2+}$, $\mathrm{PO}_{4}{ }^{3-}, \mathrm{I}^{-}, \mathrm{Cu}^{2+}, \mathrm{Br}^{-}, \mathrm{Pb}^{2+}, \mathrm{Li}^{2+}, \mathrm{Ba}^{2+}$, and $\mathrm{SO}_{4}{ }^{2-}$ is examined at a 5 -fold concentration to that of $50 \mu \mathrm{g} / \mathrm{L}$ of selenium and nickel. The obtained results after reacting with each ion confirm the negligible interference on Se (IV) and Ni (II) for the current at $50 \mu \mathrm{g} / \mathrm{L}, 100 \mu \mathrm{g} / \mathrm{L}$, and $100 \mu \mathrm{g} / \mathrm{L}$ concentrations of interfering ions (Figure 8 ). The species evaluated could not generate any current signal within the range of potentials used in voltammograms. However, a decrease in current is observed in the presence of $1000 \mu \mathrm{g} / \mathrm{L}$ of $\mathrm{Li}$ (II). But, the probabilities of existence of this much concentration of interfering ions along with $\mathrm{Se}$ (IV) and $\mathrm{Ni}$ (II) in real water are negligible. So, the developed sensor can be used for the detection of Se (IV) and Ni (II) in real water. It is important to access inference from organic compounds too since natural water contains them $[24,25]$. We did the extraction of each organic compound from the sample and dried it. 
TABLe 1: Comparison of analytical performances of reported electrodes for Se (IV) and Ni (II) sensing.

\begin{tabular}{|c|c|c|c|c|c|}
\hline Electrode & Technique & $\begin{array}{c}\text { Species } \\
\text { detected }\end{array}$ & Analytical details & Detection matrix & Reported by \\
\hline $\begin{array}{l}\text { Pencil } \\
\text { graphite }\end{array}$ & $\mathrm{CV}$ & $\mathrm{Se}^{4+}$ & $\begin{array}{l}50 \mathrm{~nm} \text { to } 110 \mathrm{~nm} \\
\text { LOD: } 16.58 \mathrm{~nm}\end{array}$ & Food and water samples & Azizi and group [24] \\
\hline $\mathrm{DMG} / \mathrm{CPE}$ & $\mathrm{CV}$ & $\mathrm{Ni}^{2+}$ & $4 \mathrm{mg} / \mathrm{L}$ & Mine water & $\begin{array}{l}\text { Ferancova and group } \\
\qquad[11]\end{array}$ \\
\hline $\mathrm{Au} / \mathrm{ZnO} / \mathrm{ITO}$ & SWASV & $\mathrm{Se}^{4+}$ & $\begin{array}{c}\text { 5-100 ppb } \\
\text { LOD: } 2.89 \mathrm{ppb}\end{array}$ & Aqueous solutions & Jain and group [8] \\
\hline GCE-AuNPs & SWASV & $\mathrm{Se}^{4+}$ & $0.01-12 \mathrm{ppm} 0.22 \mathrm{ppb}$ & Aqueous solutions & Idris and group [25] \\
\hline $\mathrm{Pt} / \mathrm{Mn}_{3} \mathrm{O}_{4}-\mathrm{Cn}$ & $\mathrm{CV}$ & $\mathrm{Se}^{4+} \mathrm{Ni}^{2+}$ & $\begin{array}{c}5-250 \mu \mathrm{g} / \mathrm{L} \\
\text { LOD: } 0.533 \mu \mathrm{g} / \mathrm{L} \text { and } \\
0.718 \mu \mathrm{g} / \mathrm{L} \\
\end{array}$ & $\begin{array}{l}\text { Aqueous solution, tap water, lake } \\
\text { water }\end{array}$ & Present study \\
\hline
\end{tabular}

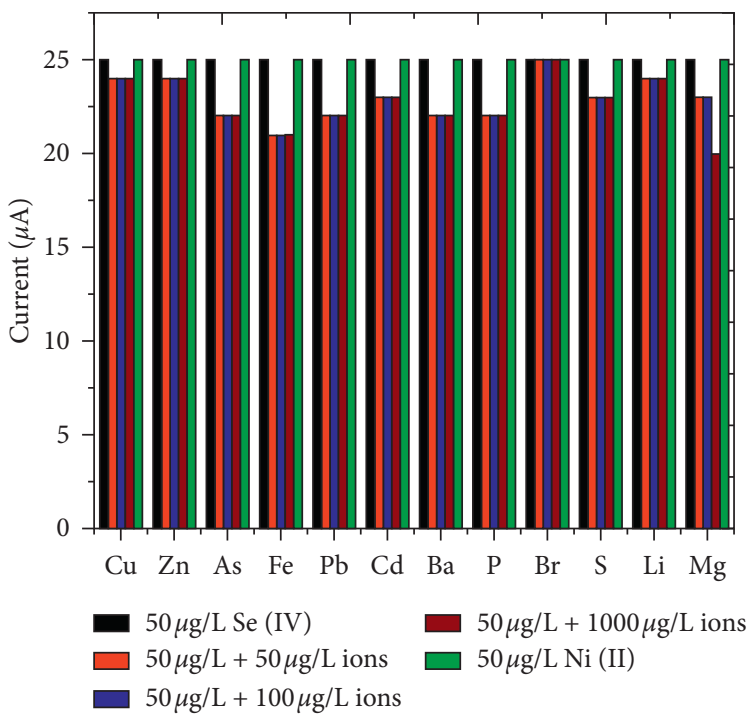

Figure 8: Comparative voltammogram response of $\mathrm{Mn}_{3} \mathrm{O}_{4}$-Cn electrode to $50 \mu \mathrm{g} / \mathrm{L}$ of $\mathrm{Se}$ (IV) and $\mathrm{Ni}$ (II) in $0.1 \mathrm{M} \mathrm{PBS}$ and $5 \mathrm{mM} \mathrm{Fe}(\mathrm{CN})_{6}$ in the presence of common interfering ions $(10 \mu \mathrm{g} / \mathrm{L}$ each $)$ at $25^{\circ} \mathrm{C}$.

After the drying process, the weight of each compound is taken $[11-20,23,24]$. The tolerance levels of organic compounds like L-cysteine, sodium dodecylbenzene sulfonate, polyethylene glycol mono-p-nonyl phenyl ether, and EDTA-2Na are $1.2 \mathrm{mg} \mathrm{L}^{-1}, 0.9 \mathrm{mg} \mathrm{L}^{-1}, 1.0 \mathrm{mg} \mathrm{L}^{-1}$, and $0.09 \mathrm{mg} \mathrm{L}^{-1}$, respectively [6].

3.7. Real-Time Analysis. The analysis is done for the purpose of the practical application of $\mathrm{Pt} / \mathrm{Mn}_{3} \mathrm{O}_{4}$-Cn electrochemical sensor in environmental detection of $\mathrm{Se}$ (IV) and $\mathrm{Ni}$ (II) in the real sample, tap water (St. Berchmans College Lab) and lake water (South Kerala, India). The $\mathrm{pH}$ of the samples is at the optimum condition as mentioned above. The standard addition method is used as a validation method to evaluate the analytical applicability in the determination of selenium and nickel using the proposed technique. The acquired water samples are first filtered through a 0.45 -micron filter to get rid of suspended particles and then added with $10 \mu \mathrm{g} / \mathrm{L}$ of selenium and nickel. With the standard addition method, $10 \mathrm{~mL}$ electrochemical cells comprising $2 \mathrm{~mL}$ of both tap water and lake water sample alternatively, $1 \mathrm{~mL} 0.1 \mathrm{M} \mathrm{PBS}$, and known Se (IV) and Ni (II) concentrations are analyzed consecutively. Even without spiking, the $\mathrm{Mn}_{3} \mathrm{O}_{4}$ - $\mathrm{Cn}$ electrode is sensitive enough to sense Se (IV) and $\mathrm{Ni}$ (II) in tap water ensuring its applicability and sensitivity. It is necessary to validate the accuracy of this technique; therefore, the electrodes are tested via a certified reference material (TM15) with a concentration of $15 \mu \mathrm{g} / \mathrm{L}$ Se (IV) and Ni (II). However, another approach using ICP-MS for water samples is done to specifically rule out any interference from foreign ions. We observed reasonable recovery, which showed the capability of $\mathrm{Mn}_{3} \mathrm{O}_{4}$ - $\mathrm{Cn}$ for detecting Se (IV) and $\mathrm{Ni}$ (II) in real water samples. The analysis is carried out in quadruple where a relative error of $5.98 \%$ is obtained for $\mathrm{Pt} / \mathrm{Mn}_{3} \mathrm{O}_{4}-\mathrm{Cn}$. However, no major differences between the theoretical and experimental values are observed. Table 2 summarizes the analytical results of $\mathrm{Se}$ (IV) and $\mathrm{Ni}$ (II) concentrations in tap water and lake water on four replicate analyses.

The lake water sample has higher concentrations of selenium with reference to the World Health Organization (WHO) guideline of $10 \mu \mathrm{g} / \mathrm{L}$ for Se (IV) and $20 \mu \mathrm{g} / \mathrm{L}$ for $\mathrm{Ni}$ (II). But, a higher concentration is noted during the summers while, in the monsoon season, lower concentrations are recorded. This might have occurred due to dilution from 
TABLE 2: Analytical results of real water samples.

\begin{tabular}{|c|c|c|c|c|}
\hline Metal ions & On-site collection of samples & Added in sample, $\mu \mathrm{g} / \mathrm{L}$ & Determined in sample $\mu \mathrm{g} / \mathrm{L}$ & Recovery (\%) \\
\hline $\mathrm{Ni}$ (II) & & & 10.5 & 102 \\
\hline Se (IV) & Tap water & 10 & 9.75 & 97 \\
\hline ICP-MS & & & 10.3 & 101 \\
\hline \multirow{4}{*}{ Se (IV) } & Site 1 & \multirow{4}{*}{10} & $28.6 \pm 0.03$ & 120 \\
\hline & Site 2 & & $18.67 \pm 0.05$ & 115 \\
\hline & Site 3 & & $14.8 \pm 0.06$ & 110 \\
\hline & Site 4 & & $17.6 \pm 0.03$ & 115 \\
\hline \multirow{4}{*}{$\mathrm{Ni}$ (II) } & Site 1 & \multirow{4}{*}{10} & $31.2 \pm 0.12$ & 125 \\
\hline & Site 2 & & $35.3 \pm 1.3$ & 111 \\
\hline & Site 3 & & $28.9 \pm 0.7$ & 117 \\
\hline & Site 4 & & $30.4 \pm 0.01$ & 110 \\
\hline \multirow{2}{*}{ ICP-MS } & Site $1, \mathrm{Se}$ & \multirow{2}{*}{10} & $27.5 \pm 0.037$ & 120 \\
\hline & Site $2, \mathrm{Ni}$ & & $32.2 \pm 0.075$ & 111 \\
\hline
\end{tabular}

TABLE 3: Analytical results of real water samples collected during shutdown of factory.

\begin{tabular}{|c|c|c|c|c|}
\hline Sample & On-site collection of samples & Added in sample, $\mu \mathrm{g} / \mathrm{L}$ & Determined in sample $\mu \mathrm{g} / \mathrm{L}$ & Recovery (\%) \\
\hline \multirow{4}{*}{ Se (IV) } & Site 1 & \multirow{4}{*}{10} & $11.2 \pm 0.05$ & 110 \\
\hline & Site 2 & & $9.25 \pm 0.07$ & 92 \\
\hline & & & $18.5 \pm 0.03$ & 111 \\
\hline & & & $17.4 \pm 0.01$ & 113 \\
\hline \multirow{2}{*}{$\mathrm{Ni}(\mathrm{II})$} & Site 2 & \multirow{2}{*}{10} & $10.6 \pm 0.05$ & 100 \\
\hline & Site 4 & & $10.3 \pm 0.04$ & 101 \\
\hline \multirow{2}{*}{ ICP-MS } & Site $2, \mathrm{Se}$ & \multirow{2}{*}{10} & $15.8 \pm 0.56$ & 105 \\
\hline & Site $4, \mathrm{Ni}$ & & $16.7 \pm 0.12$ & 107 \\
\hline
\end{tabular}

higher rainwater runoff and flows. The concentration of Se (IV) and $\mathrm{Ni}$ (II) in tap water are within the limit of WHO guidelines. Our projected technique could be used for the speciation investigation of natural water samples with adequate results. We also collected the sample from the lake during summer when the factory is closed due to a strike for above one month. The results are noteworthy as there is a decrease in the traces of Se (IV) and Ni (II) in the collected samples and detailed out in Table 3.

\section{Conclusions}

The detection of $\mathrm{Se}$ (IV) and $\mathrm{Ni}$ (II) using $\mathrm{Mn}_{3} \mathrm{O}_{4}-\mathrm{Cn}$ is successfully demonstrated. In low concentrations, $\mathrm{CV}$ is a more appropriate method as Se (IV) and Ni (II) exhibit characteristic voltammetric waves of peak heights relevant to selenium concentration. The working electrode of $\mathrm{Mn}_{3} \mathrm{O}_{4^{-}}$ $\mathrm{Cn}$ is fabricated and used to evaluate the voltammetric behavior of selenium and nickel using the cyclic voltammetry method. CV is a relevant technique to understand electron transfer at the electrode-solution interface, especially for low concentrations. Supporting electrolyte concentration, scan rate, and the number of cyclic repetition is observed for their influence on selenium and nickel peak shape and intensity The results from $\mathrm{CV}$ indicate that the presence of $\mathrm{Mn}_{3} \mathrm{O}_{4}$ helps to enable the electrochemically reversible electron transfer. Optimization of the parameters of this technique has been carried out for consistent and reproducible results by parallel assemblies of $\mathrm{Mn}_{3} \mathrm{O}_{4}$, which amplifies the current response. $\mathrm{Mn}_{3} \mathrm{O}_{4}$-Cn electrode offers advantages of low cost, low detection limit, low response time, and high sensitivity. The $\mathrm{Se}$ and $\mathrm{Ni}$ redox reaction appears to be kinetically faster and more reversible. Selenium and nickel concentrations are detected in tap water and lake water. $\mathrm{Pt} / \mathrm{Mn}_{3} \mathrm{O}_{4}-\mathrm{Cn}$ is successfully working on the analysis of real water samples, and the results allied with the ICP-MS analysis with recoveries greater than $96 \%$. Due to the practical protection of fabricated electrodes toward frequently found interfering ions during quantification, it is effectively verified for real water sample analysis. We had limitations in obtaining results for concentrations below $5 \mu \mathrm{g} / \mathrm{L}$ and for higher concentrations of the detected species. Further work is underway to demonstrate the use of these sensors for testing sediment samples providing rapid on-site analysis for selenium and nickel using differential pulse voltammetry.

\section{Data Availability}

Data obtained have been plotted in graphs.

\section{Conflicts of Interest}

The authors declare that there are no conflicts of interest.

\section{Acknowledgments}

The authors thank the School of Chemical Sciences, MG University, and CSIR-CECRI for providing facilities to conduct electrochemical analysis. The authors also 
acknowledge the Optoelectronics Department, Kerala University for FESEM. The authors thank the Central Instrumentation Facility, St. Berchmans College, Changanassery, for FTIR analysis using Spectrum 2.

\section{References}

[1] Z. W. Chen, J. K. L. Lai, and C. H. Shek, "Nucleation site and mechanism leading to growth of bulk-quantity $\mathrm{Mn}_{3} \mathrm{O}_{4}$ nanorods," Applied Physics Letters, vol. 86, no. 18, Article ID 181911, 2005.

[2] K. K. Reza, N. Singh, S. K. Yadav, M. K. Singh, and A. M. Biradar, "Pearl shaped highly sensitive $\mathrm{Mn}_{3} \mathrm{O}_{4}$ nanocomposite interface for biosensor applications," Biosensors and Bioelectronics, vol. 62, pp. 47-51, 2014.

[3] J. Singh, P. Kalita, M. K. Singh, and B. D. Malhotra, "Nanostructured nickel oxide-chitosan film for application to cholesterol sensor," Applied Physics Letters, vol. 98, no. 12, Article ID 123702, 2011.

[4] K. J. Babu, M. Sasya, N. Nesakumar et al., "Non-enzymatic detection of glucose in fruits using $\mathrm{TiO}_{2}-\mathrm{Mn}_{3} \mathrm{O}_{4}$ hybrid nano interface," Applied Nanoscience, vol. 6, pp. 309-316, 2017.

[5] F. A. Bertolino, A. A. J. Torriero, E. Salinas, R. Olsina, L. D. Martinez, and J. Raba, "Speciation analysis of selenium in natural water using square-wave voltammetry after preconcentration on activated carbon," Analytica Chimica Acta, vol. 572, no. 1, pp. 32-38, 2006.

[6] J. Long and Y. Nagaosa, "Determination of selenium (IV) by catalytic stripping voltammetry with an in situ plated bismuth-film electrode," Analytical Sciences, vol. 23, no. 11, pp. 1343-1346, 2007.

[7] S. H. Tan and S. P. Kounaves, "Determination of selenium (IV) at a microfabricated gold ultramicroelectrode array using square wave anodic stripping voltammetry," Electroanalysis, vol. 10, no. 6, pp. 364-368, 1998.

[8] R. Jain, A. Thakur, P. Kumar, and D. Pooja, "Au/ZnO nanocomposites decorated ITO electrodes for voltammetric sensing of selenium in water," Electrochimica Acta, vol. 290, pp. 291-302, 2018.

[9] R. W. Andrews and D. C. Johnson, "Voltammetric deposition and stripping of selenium (IV) at a rotating gold-disk electrode in $0.1 \mathrm{~m}$ perchloric acid," Analytical Chemistry, vol. 47, no. 2, pp. 294-299, 1975.

[10] F. Dara, I. Noviandri, and B. Buchari, "Voltammetric behavior of selenium from $\mathrm{H}_{2} \mathrm{SeO}_{3}$ solution on solid copper amalgam electrode," International Journal of engineering Research and Applications, vol. 7, no. 8, pp. 24-29, 2017.

[11] A. Ferancova, M. K. Hattuniemi, A. M. Sesay, J. P. Ra"ty, and V. T. Virtanen, "Electrochemical monitoring of nickel (II) in mine water," Mine Water Environ, vol. 35, pp. 547-552, 2014.

[12] J. Gao, M. A. Lowe, and H. D. Abruña, "Spongelike nanosized $\mathrm{Mn}_{3} \mathrm{O}_{4}$ as a high-capacity anode material for rechargeable lithium batteries," Chemistry of Materials, vol. 23, no. 13, pp. 3223-3227, 2011.

[13] M. M. Samira, T. Hazhir, S. Abdollah, and H. Rahman, "Fabrication of electrochemical theophylline sensor based on manganese oxide nanoparticles/ionic liquid/chitosan nanocomposite modified glassy carbon electrode," Electrochimica Acta, vol. 108, pp. 707-716, 2013.

[14] S. M. Majd, H. Teymourian, and A. Salimi, "Fabrication of an electrochemicalL-cysteine sensor based on graphene nanosheets decorated manganese oxide nanocomposite modified glassy carbon electrode," Electroanalysis, vol. 25, no. 9, pp. 2201-2210, 2013.
[15] L. E. Eary and D. Rai, "Kinetics of chromium (III) oxidation to chromium (VI) by reaction with manganese dioxide," Environmental Science \& Technology, vol. 21, no. 12, pp. 11871193, 1987.

[16] P. S. Adarakattil, V. K. Gangaiah, C. E. Banks, and A. Siddaramanna, "One-pot synthesis of $\mathrm{Mn}_{3} \mathrm{O}_{4}$ /graphitic carbon nanoparticles for simultaneous nanomolar detection of $\mathrm{Pb}$ (II), Cd (II) and Hg (II)," Journal of Materials Science, vol. 53, no. 7, 2017.

[17] L. Wang, K. L. Wu, B. B. Jiang et al., "Non-enzymatic electrochemical sensors for the detection of $\mathrm{H}_{2} \mathrm{O}_{2}$ based on $\mathrm{Mn}_{3} \mathrm{O}_{4}$ octahedron submicrostructures," Micro \& Nano Letters, vol. 9, no. 10, pp. 736-740, 2014.

[18] Q. Hao, J. Wang, and C. Xu, "Facile preparation of $\mathrm{Mn}_{3} \mathrm{O}_{4}$ octahedra and their long-term cycle life as an anode material for Li-ion batteries," Journal of Materials Chemistry A, vol. 2, no. 1, pp. 87-93, 2014.

[19] J. Li, L. Li, F. Wu, L. Zhang, and X. Liu, "Dispersion-precipitation synthesis of nanorod $\mathrm{Mn}_{3} \mathrm{O}_{4}$ with high reducibility and the catalytic complete oxidation of air pollutants," $\mathrm{Ca}$ talysis Communications, vol. 31, pp. 52-56, 2013.

[20] N. John, P. Thomas, K. V. Divya, and K. E. Abraham, "Enhanced room temperature gas sensing of aligned $\mathrm{Mn}_{3} \mathrm{O}_{4}$ nanorod assemblies functionalized by aluminum anodic membranes," Nanotechnology, vol. 29, no. 33, Article ID 335503, 2018.

[21] M. Ochab, I. Gęca, and M. Korolczuk, "Determination of trace Se (IV) by anodic stripping voltammetry following double deposition and stripping steps," Talanta, vol. 165, pp. 364368, 2016.

[22] C. T. Fakude, O. A. Arotiba, R. Moutloali, and N. Mabuba, "Nitrogendoped graphene electrochemical sensor for selenium (IV) in water," International Journal of Electrochemical Science, vol. 14, pp. 9391-9403, 2019.

[23] A. B. Chimezie, R. Hajian, N. A. Yusof, P. M. Woi, and N. Shams, "Fabrication of reduced graphene oxide-magnetic nanocomposite ( $\mathrm{rGO}-\mathrm{Fe}_{3} \mathrm{O}_{4}$ ) as an electrochemical sensor for trace determination of As (III) in water resources," Journal of Electroanalytical Chemistry, vol. 796, pp. 33-42, 2017.

[24] Z. Azizi and A. Babakhanian, "Fabricating a new electrochemically modified pencil graphite electrode based on acetophenone (2, 4-dinitrophenyl) hydrazone for determining selenium in food and water samples," Analytical Methods, vol. 10 , no. 6 , pp. 5205-5213, 2018.

[25] A. O. Idris, N. Mabuba, and O. A. Arotiba, "Electrochemical co-detection of arsenic and selenium on a glassy carbon electrode modified with gold nanoparticles," International Journal of Electrochemical Science, vol. 12, pp. 10-21, 2017. 